\title{
Brush Border and Cytosol Peptidase Activities of Human Small Intestine in Normal Subjects and Celiac Patients
}

\author{
(GENEROSO ANIDRIA. SALVATORE ( UCCHIARA. BASILIO DE VIZIA, (GIORGIO DEE RITIS, \\ (IABRIELE MAZZACCA. ANI SALVATORE AURICCIIIO \\ Department of Pediatrics and Department of (iastroenterology. II Faculty of Medicine. University of Naples. Naples. \\ ltaly and (onsiglio Nazionale delle Ricerche. Program of Preventive Medicine (Project of Perinatal Medicine). \\ Rome. Italy.
}

\begin{abstract}
Summary
Peptidase activities have been investigated in the brush border of human proximal jejunum by using dipeptides and tripeptides and $\beta$-naphthylamides of glycyl- $L$-proline and amino acids as substrates. The activities hydrolyzing glycyl-L.-leucine, 1 --phenylalanylI-alanine, and I--leucylglycylglycine in the brush border were found to be only 1.5, 15, and $16 \%$ of the total peptidase activities present in the intestinal mucosa, but the specific activities for the hydrolysis of these substrates appeared in the brush border to be as high as or higher than that of sucrase. The enzyme(s) hydrolyzing $\mathrm{L}$ phenylalanyl- $t$-alanine in the brush border showed different properties from the enzyme(s) hydrolyzing the same substrate in the cytosol, the former being completely resistant to $p$-hydroxymercuribenzoate, partially resistant to heating, and inhibited by puromycin by about $50 \%$. On the other hand, the enzymatic activities hydrolyzing the $\beta$-naphthylamides of glycyl-1,-proline, 1 -leucine, and $\alpha-1$-glutamic acid as well as $N$-carbobenzoxy-1,-prolyl-I,-alanine were shown to be almost totally localized in the brush border. All the peptidase and $\beta$-naphthylamidase activities studied were well solubilized by papain from the brush border membrane with the only exception being the activity hydrolyzing glycyl-I.-leucine. By acrylamide gel electrophoresis, three enzymatic activities were clearly separated from each other as well as from the oligoaminopeptidase- (EC 3.4.11.2) splitting 1--leucyl- $\beta$-naphthylamide: (1) the aminopeptidase $A$ (EC 3.4.11.7) hydrolyzing $\alpha$-1-glutamyl- $\beta$ naphthylamide: (2) the dipeptidylaminopeptidase IV (EC 3.4.14.-) liberating glycyl-1.-proline from glycyl-t.-prolyl- $\beta$-naphthylamide; and (3) a carboxypeptidase hydrolyzing $N$-carbobenzoxy-l.-prolyl1.-alanine (EC 3.4.12.-).

Brush border peptidases (oligoaminopeptidase, aminopeptidase A, dipeptidylaminopeptidase IV, and carboxypeptidase) and cytosol dipeptidase and tripeptidase activities were measured in intestinal biopsies of celiac patients utilizing specific substrates.

These enzymatic activities were normal in eight children with celiac disease in histologic remission, with only aminopeptidase $A$ being reduced to $70 \%$ of control values. On the contrary, in the atrophic mucosa of 12 children with active celiac disease, these were all significantly but not equally reduced.
\end{abstract}

\section{Speculation}

The identification of the above-mentioned peptidases in the intestinal brush border demonstrates the importance of this subcellular organelle in the digestion of protein and peptides complementary to intraluminal and intracellular digestion. Brush border peptidases are probably involved in the digestion of gliadin, which is very rich in glut amic acid and proline residues; as these activities are lowered in the atrophic celiac mucosa, digestibility of gliadin peptides might be reduced during active celiac disease.
Studies in animals have demonstrated two major subcellular localization of digestive peptidases in the enterocyte. cytosol, and brush border. Most of the enzymatic activity hydrolyzing dipeptides and tripeptides is localized in the cytosol $(1,16,17,21,26$. $32,35,42,46,49,53,54,60)$ with few exceptions $(25,26,42,46$. 49, 60): three soluble enzymes with dipeptidase and tripeptidase activity have been purified and characterized $(12,15,16,20,48$, 51. 62). Almost all the enzymatic activities hydrolyzing the $\beta$ naphthylamides of amino acids $(6,21,26,29,42,46,54,60)$ (with the exception of I-arginyl-and L-lysy!- $\beta$-naphthylamide) (30) and of glycyl-1.-proline $(6,14,34)$ as well as that hydrolyzing $N$ carbobenzoxy-L-prolyl-L-alanine ( $N$-CBZ-1-prolyl-1-alanine) or $N$-CBZ-1.-prolyl-I.-leucine (6) are, on the contrary, localized in the brush border: these are due to the following brush border peptidases: (1) oligoaminopeptidase (substrate, I--leucyl- $\beta$-naphthylamide) which has been purified from hog $(42,61)$, rabbit $(66)$. and rat $(23,36,37)$ intestine: (2) aminopeptidase A (substrate $\alpha-L-$ glutamyl-( $\beta$-naphthylamide): and (3) dipeptidylaminopeptidase IV (substrate. glycyl-I -prolyl- $\beta$-naphthylamide): These two enzymes have been demonstrated in rabbit $(6)$ and hog $(14,34)$ intestine. The dipeptidylaminopeptidase has been purified from hog intestine (65): (4) a carboxypeptidase [substrate, $N$-carbobenzoxy-1.prolyl-1-alanine ( $N$-C BZ-L-prolyl-I-alanine) or I-leucine] which has been demonstrated in rabbit intestine (6).

The cytosol peptidases appear to be responsible for the digestion of the dipeptides and tripeptides, which are transported into the cell by the carrier for di- and tripeptides present in the brush border $(18,43,55)$. The brush border peptidases on the contrary are probably specialized in the hydrolysis of peptides containing glutamic acid and proline as well as in the hydrolysis of larger peptides (13), with different mechanism (aminopeptidase. dipeptidylaminopeptidase. endopeptidase, and carboxypeptidase hydrolysis) (6, 11).

Very few data are available in the literature on the brush border peptidases of human intestine: oligoaminopeptidase is the only enzyme which has been purified (22). We have recently demonstrated that aminopeptidase A, dipeptidylaminopeptidase IV, and the carboxypeptidase, hydrolyzing $N$-CBZ-1.-prolyl-L-alanine or $N$-carbobenzoxy-I-prolyl-I-alanine ( $N$-CBZ-1-prolyl-1-leucine), are also present in the brush border of human small intestine ( 3 , 7). Similar results were obtained for aminopeptidase A by Sterchi and Woodley (64) and for dipeptidylaminopeptidase IV by Sterchi and Woodley (64) as well as by Skovbjerg et al. (63).

In this paper, we present our studies in extenso on the brush border peptidases of human intestine. We also confirm that in human intestinal mucosa the hydrolysis of glycyl-1-leucine and of L-leucylglycylglycine is mainly due to cytosol enzymes. We demonstrate that it is possible to measure with specific su'strates the activity of cytosol and brush border peptidases in total homogenate of intestinal biopsies. Finally, we measure these different 
enzymatic activities in biopsies of small intestinal mucosa of celiac patients.

\section{MATERIALS AND METHODS}

\section{ENZYMES OF JEJUNAI. MUCOSA FROM ADULT SUBJECTS}

Macroscopically normal strips of intestinal mucosa weighing 100 to $200 \mathrm{mg}$ were obtained from the proximal jejunum (approximately $10 \mathrm{~cm}$ from the ligament of Treitz) of patients who underwent lower partial gastrectomy and gastrojejunostomy for duodenal ulcer. All patients gave informed consent.

\section{IENZYMES OF SMALI, INTESTINAL BIOPSIES FROM CHILDREN}

Peroral small intestinal biopsies were obtained from the last part of the duodenum immediately before the flexure duodenojejunalis from: (1) 12 children with active celiac disease with subtotal mucosal atrophy: (2) 8 children with celiac disease in histologic remission after a gluten-free diet. The intestinal mucosa was completely normal in 4 children and slightly abnormal (only minimal architectural changes of the villi with no abnormality in the surface epithelial cells) in 4 children; (3) 9 children with unspecific chronic diarrhea (19) and with histologically normal intestinal mucosa.

Diagnosis of celiac disease was made on the basis of the following criteria: malabsorption syndrome and typical histologic lesion of distal duodenal mucosa, both healing after several months of gluten-free diet and relapsing after the reintroduction of gluten in the diet.

Biopsy specimens were divided into two pieces, one for histologic studies and one for the enzymatic assay.

\section{ENZYME ASSAYS}

Specimens used for enzymatic studies were rinsed in cold saline and immediately processed for the assay of the enzymatic activities hydrolyzing 1--phenylalanyl-1-alanine, glycyl-1-leucine, and I--leucylglycylglycine; the cytosol enzymes hydrolyzing these substrates were in fact labile at $-20^{\circ} \mathrm{C}$. For all other experiments, the pieces of small intestine were frozen at $-20^{\circ} \mathrm{C}$ for 1 to 4 months. The other enzymatic activities were stable under these conditions for at least 4 months. To study the subcellular distribution of the enzymatic activities, brush border was prepared according to Schmitz et al. (57).

The peptidase and $\beta$-naphthylamidase activities were assayed as previously described $(2,6)$. The incubation mixtures for the different substrates were at the optimal $\mathrm{pH}$ for the brush border and cytosol enzymes (see "Results"). A unit of enzyme activity hydrolyzes $1 \mu$ mole of substrate per min. All enzymatic activities were proportional to the incubation time and to the enzyme concentration when the assay mixtures contained 0.25 to 2 munits of peptidase and 0.05 to 0.4 munit of amino acyl- or dipeptidyl$\beta$-naphthylamide hydrolase activity. Sucrase activity was measured by the method of Auricchio et al. (5). Succinate dehydrogenase, NADPH-cytochrome c reductase. and $\beta$-glucuronidase activities were assayed according to the methods used by Schmitz et al. (57). The products formed from the hydrolysis of glycyl-Lprolyl- $\beta$-naphthylamide were identified by high-voltage electrophoresis on paper $(6)$.

\section{PROTEIN CONCENTRATION}

Protein concentration was estimated by the method of Lowry et al. (41) with bovine albumin as a standard.

\section{THE EFFECT OF PUROMYCIN. P-HYDROXYMERCURIBENZOATE AND HEATING;}

The effect on peptidase activities was studied under the conditions described in a previous report (2).

\section{PAPAIN SOLUBILIZATION AND ACRYLAMIDE GEI} EI.ECTROPHORESIS

These were carried out according to the methods previously reported $(6)$.

\section{REACIENTS}

Substrates and reagents used were as described in previous reports $(2,6,8,9)$.

\section{RESULTS}

PEPTIDASF ACTIVITIES OF SMALI. INTESTINAL MUCOSA IN NORMAL ADULTS

The optimal $\mathrm{pH}$ for the hydrolysis in the brush border of the different substrates were the following: in Tris-HCl buffer, $\mathrm{pH} 8$ for $\alpha$-I.-glutamyl-, glycyl-1-prolyl- $\beta$-naphthylamide, and 1 -phenylalanyl-1-alanine and $\mathrm{pH} 7.5$ for glycyl-1-leucine and I-leucylglycylglycine; in veronal buffer, $\mathrm{pH} 7.8$ for $N$-CBZ-I-prolyl-1.alanine: in phosphate buffer, $\mathrm{pH} 7.5$ for I-leucyl- $\beta$-naphthylamide.

The optimal $\mathrm{pH}$ for the hydrolysis in the cytosol of glycyl-Ileucine and L-leucylglycylglycine was 7.5 in Tris- $\mathrm{HCl}$ buffer.

The enzymatic hydrolysis of glycyl-L-leucine, L-phenylalanyl-Lalanine, and 1 --leucylglycylglycine in intestinal mucosa is mainly due to enzyme(s) not located in the brush border. Assuming a $100 \%$ recovery of the sucrase activity in this subcellular fraction. the recovery in the brush border was $1.5 \% \pm 0.6,15 \% \pm 1.3$, and $16 \% \pm 5$, respectively, for the hydrolysis of the three substrates. On the contrary, the recovery was $83 \% \pm 10.78 \% \pm 9$, and $80 \%$ \pm 9 (mean \pm S.E. of 4 different preparations) in the supernatant [S.: fraction according to Schmitz et al. (57)]. Nevertheless, these three enzymatic activities showed in the brush border a specific activity (units $/ \mathrm{mg}$ of protein) as high as or higher than that of sucrase: $0.6 \pm 0.33,0.85 \pm 0.35$, and $0.32 \pm 0.07$ for the hydrolysis of glycyl-L-leucine, L-phenylalanyl-L-alanine, and I-leucylglycylglycine, respectively, and $0.33 \pm 0.15$ for the hydrolysis of sucrose

The enzyme(s) hydrolyzing $\mathrm{L}$-phenylalanyl-L-alanine in the brush border appears to be different from the enzyme(s) hydrolyzing the same substrate in the supernatant at $105.000 \times g$ ["soluble" enzyme(s)]; the hydrolysis of the dipeptide in the brush border was completely resistant to $p$-hydroxymercuribenzoate and partially resistant to heating. It was also inhibited by puromycin by about $50 \%$. These properties were opposite to those of the enzymatic activity of the cytosol, which was completely inhibited by $p$-hydroxymercuribenzoate: it was less resistant to heating and was not inhibited by puromycin. The enzymatic activity hydrolyzing glycyl-t-leucine in the brush border was not influenced by puromycin.

The enzymatic activities hydrolyzing the $\beta$-naphthylamides of amino acids as well as $N$-CBZ-L-prolyl-L-alanine are mainly located in the brush border. Assuming a 100\% recovery of the sucrase activity in this subcellular fraction, the recovery in the hrush border ranged between 70 and $98 \%$ for the hydrolysis of the different substrates (see Table 1). All these enzymatic activities were purified over 12 -fold in the brush border fraction. as compared to the total homogenate.

The enzymatic hydrolysis of $N$-CBZ-L-prolyl-1-alanine was activated by $\mathrm{Co}^{2+}$ and inhibited by EDTA and $o$-phenanthroline as well as by 3-phenylpropionate, which is an inhibitor of various carboxypeptidases $(24,44)$. The enzymatic hydrolysis of $\alpha$-L-glutamyl- $\beta$-naphthylamide was activated by $\mathrm{Ca}^{2+}$ and inhibited by EDTA and $o$-phenanthroline. The enzymatic hydrolysis of glycyl$L$-prolyl- $\beta$-naphthylamide was neither activated by metal ions nor inhibited by EDTA or $o$-phenanthroline (Table 2). Papain solubilized the brush border $\beta$-naphthylamidase and peptidase activities under study by various degrees ranging between 65 and $90 \%$. On the contrary, only $20 \%$ of the enzymatic activity hydrolyzing glycyl-1-leucine was solubilized. 
Acrylamide gel electrophoresis (Fig. 1) separated from eac other glycyl-1.-prolyl- $\beta$-naphthylamide, $\alpha-1$-glutamyl- $\beta$-naphthy amide. I-leucyl- $\beta$-naphthylamide, and $N$-CBZ-I-prolyl-1-alanir hydrolase activities. The enzyme activities hydrolyzing 1-pher ylalanyl-1-alanine, glycyl-1-leucine, 1-methionyl-1-leucine, and 1 leucylglycylglycine were coincident with the peak of 1-leucyl-/ naphthylamide hydrolase activity.

The dipeptidyl-aminopeptidase eluted from the gel was able t hydrolyze glycyl-I-prolyl- $\beta$-naphthylamide into glycyl-1-prolin and $\beta$-naphthylamine.

\section{PEPTIDASK ACTIVITIES OF SMALL. INTESTINAL BIOPSIES IN (HIIDRIN}

Brush border peptidases (oligoaminopeptidase. substrate, I-leu cyl- $\beta$-naphthylamide: aminopeptidase A, substrate, $\alpha$-I.-glutamy] $\beta$-naphthylamide: dipeptidylaminopeptidase IV. substrate, glycyl 1-prolyl- $\beta$-naphthylamide: carboxypeptidase, substrate. $N$-CBZ I-prolyl-1-leucine. and cytosol dipeptidase. substrate. glycyl-I.-leu cine) and tripeptidase (substrate, t-leucylglycylglycine) activitie were measured in total homogenate of intestinal biopsies.

Sucrase and peptidase activities were the same in adults an control children (Table 3 ).

In children with celiac disease in complete or almost complet. histologic remission after a gluten-free diet. peptidase activitie were not significantly different from control values, with th exception of the brush border enzyme aminopeptidase $A$ (sub strate. $\alpha$-I-glutamyl- $\beta$-naphthylamide) (Table 3 ), which was re duced to $70 \%$ of the control value.

In atrophic intestinal mucosa of children with active celiar disease, all the enzymatic activities studied were, on the contrary significantly reduced compared to normal controls (Table 3) Nevertheless, the peptidase activities were not equally reduced ir the atrophic mucosa. Of the brush border peptidases, aminopep. tidase $A$ and carboxypeptidase were as low as sucrase (31.2. 46.5 and 34.6 " ' of control values, respectively): dipeptidylaminopepti. dase IV and oligoaminopeptidase were, on the contrary, les: markedly reduced $(63.8$ and $70.2 \%$ of control values, respectively) Of the soluble peptidase activities, glycyl-1-leucine hydrolase activity showed a greater reduction than did 1--leucylglycylglycine hydrolase activity ( 46 and $81.5 \%$ of control values, respectively).

\section{I)ISCUSSION}

\section{PEPTIDASE ACTIVITIES IN NORMAL ADLILTS}

Although the bulk of most dipeptidase (1, 16, 17, 21, 26, 32, 35. $42,46,49,53,54,60)$ and tripeptidase $(1,21,35)$ activities is in the cytosol, the brush border of the enterocyte of rat $(8,9,21.35,38$. 39,67 ), rabbit (1.2), hamster (52), guinea pig (50), and man (28) has been found to be able to hydrolyze some peptides with high specific activity.

Our results demonstrate that in man. the enzymatic hydrolysis of glycyl-1-leucine, I--phenylalanyl-1-alanine, and I.-leucylglycylglycine in intestinal mucosa is mainly due to enzymes not located in the brush border. Nevertheless, the brush border does hydrolyze these substrates with high specific activities comparable to that of sucrase. These peptides are therefore presumably hydrolyzed in vivo, in part at least, in the brush border membrane.

The enzymatic activities hydrolyzing the $\beta$-naphthylamides of 1.-leucine, $\alpha$-1-glutamic acid, glycyl-1-proline and $N$-CBZ-1-prolyl-I.-alanine are, on the contrary, almost totally localized in the brush border. Our results as well as those of Sterchi and Woodley (64) and of Skovbjerg et al. (63) demonstrate that four different enzymes are responsible for the hydrolysis of these substrates in the human brush border: (1) an oligoaminopeptidase (substrate. I.-leucyl- $\beta$-naphthylamide). The enzyme is able to hydrolyze diand oligopeptides, up to at least octapeptides (37): the best substrates for the human enzyme are peptides, especially tri- and tetrapeptides, with a large neutral or aromatic amino acid at the $\mathrm{N}$-terminal $(22,33) ;(2)$ an aminopeptidase A (substrate, a-1- 
Table 2. Effect of ions and enzyme inhibitors on peptidase activities of human hrush border ${ }^{1}$

\section{Substrates}

$\begin{array}{ccccc}\text { Concentration } & N \text {-CBZ-I-prolyl- } & \text { Glycyl-I-prolyl- } & \alpha \text {-L-Glutamyl- } & \text { I-Leucyl- } \\ (\mathrm{mM}) & \text { I-alanine } & \beta \text {-naphthylamide } & \beta \text {-naphthylamide } & \beta \text {-naphthylamide }\end{array}$

Cations

$\begin{array}{lrrrrr}\text { None } & & 100 & 100 & 100 & 100 \\ \mathrm{Mg}^{2+} & 1 & 86 & 114 & 101 & 107 \\ \mathrm{Mn}^{2+} & 1 & 124 & 100 & 83 & 102 \\ \mathrm{Co}^{2+} & 1 & 159 & 47 & 39 & 137 \\ \mathrm{Zn}^{2+} & 1 & 32 & 96 & 102 & 103 \\ \mathrm{Ca}^{2+} & 1 & 94 & 103 & 145 & 108\end{array}$

Inhibitors

$\begin{array}{ll}\text { None } & \\ p \text {-Hydroxymercuribenzoate } & 0 \\ \text { EDTA } & 1 \\ \text { o-Phenanthroline } & 1 \\ \text { lodoacetate } & 2 \\ \text { Sodium fluoride } & 1 \\ \text { Puromycin } & 2 \\ \text { 3-Phenylpropionate } & 1\end{array}$

\begin{tabular}{lrrrr} 
& 100 & 100 & 100 & $1(0)$ \\
0.1 & 90 & 100 & 104 & 94 \\
1 & 53 & 101 & 57 & 114 \\
1 & 29 & 102 & 25 & 24 \\
2 & 71 & 94 & 72 & 95 \\
1 & 93 & 112 & 102 & 106 \\
1 & 87 & 104 & 38 & 52 \\
2 & 17 & 100 & 97 & 99 \\
\hline
\end{tabular}

Aliquots of purified brush border were assayed for the hydrolysis of the different substrates at the optimal $\mathrm{pH}$ in the absence and the presence of each of the agents listed Cations were used as chloride ions. Cations and inhibitors were preincubated with the enzyme for 20 min at $37^{\circ} \mathrm{C}$ prior to the addition of the substrate. Results given are the means of values obtained in two separate experiments. Appropriate controls showed that none of these agents interfered with the assay.

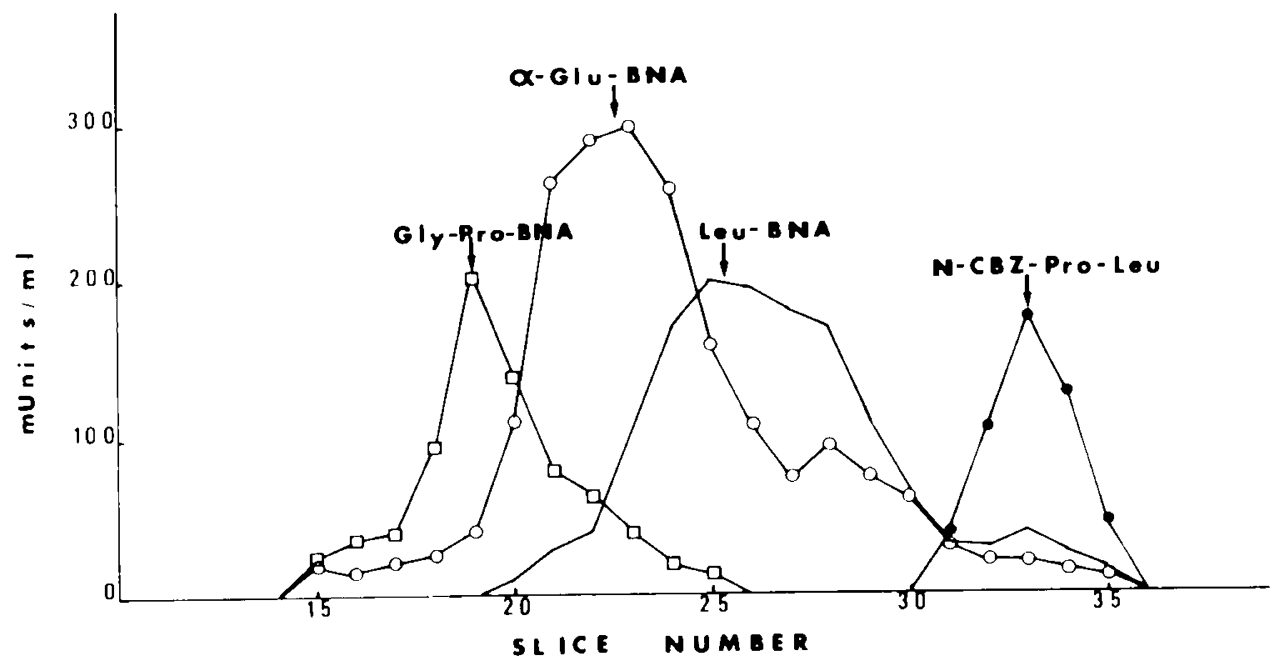

Fig. 1. Acrylamide gradient gel electrophoresis of papain-solubilized brush border enzymatic activities. The supernatant after papain digestion and centrifugation was concentrated by ultrafiltration to a final protein concentration of $2.7 \mathrm{mg} / \mathrm{ml}$. Protein. $2.7 \mathrm{mg}$. was applied to the surface of the slab of gradient gel. After the electrophoretic run, the gel was cut in $1.8-\mathrm{mm}$ slices. Each slice was placed in a tube containing $1 \mathrm{ml}$ of cold water and homogenized. The supernatant of each slice was utilized for the assay of the enzymatic activities hydrolyzing: 1-leucyl- $\beta$-naphthylamide (Letu-BN.A)

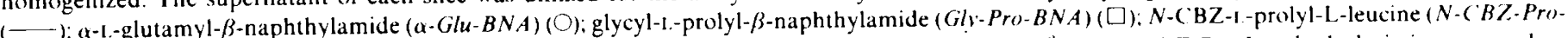

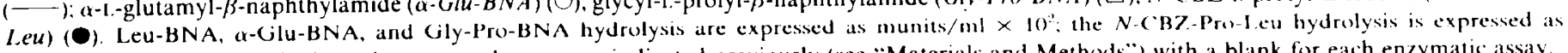
munits $/ \mathrm{ml} \times 10$. The incubation mixture was the same as indicated previously (see "Materials and Methods") with a blank for each enzymatic assay.

The activity hydrolyzing I-phenylalanyl-L-alanine, glycyl-L-leucine, L-methionyl-L-leucine, and I-leucylglycylglycine were coincident with the peak of $\mathrm{I}$-leucyl- $\beta$-naphthylamide hydrolase activity

In 4 of 8 specimens of human jejunal mucosa examined, two peaks of 1-leucyl- $\beta$-naphthylamide hydrolase activity were obtained. In these electrophoretic runs, I-phenylalanyl-L-alanine, glycyl-1-leucine, and I-leucylglycylglycine hydrolase activities showed two peaks corresponding to those of that 1 -leucyl- $\beta$-naphthylamide hydrolase activity.

glutamyl- $\beta$-naphthylamide). The enzyme is activated by $\mathrm{Ca}^{2+} ;(3)$ a carboxypeptidase (substrate, $N$-CBZ-I.-prolyl-1-alanine or L-leucine). This enzyme is activated by $\mathrm{Co}^{2+}$; and (4) a dipeptidylaminopeptidase (substrate, glycyl-L-prolyl- $\beta$-naphthylamide). This enzyme hydrolyzes glycyl-1-proline from this substrate (dipeptidylaminopeptidase IV).
In addition to the oligoaminopeptidase. two peptidases have been recently identified in the brush border of rat intestine (59), hydrolyzing glycyl-1-leucine and L-methionyl-1-leucine. Polyacrylamide gel electrophoresis of papain-solubilized and gel-filtrated peptidases of rabbit brush border also separated two enzymes hydrolyzing these dipeptides from the dipeptidylaminopep- 


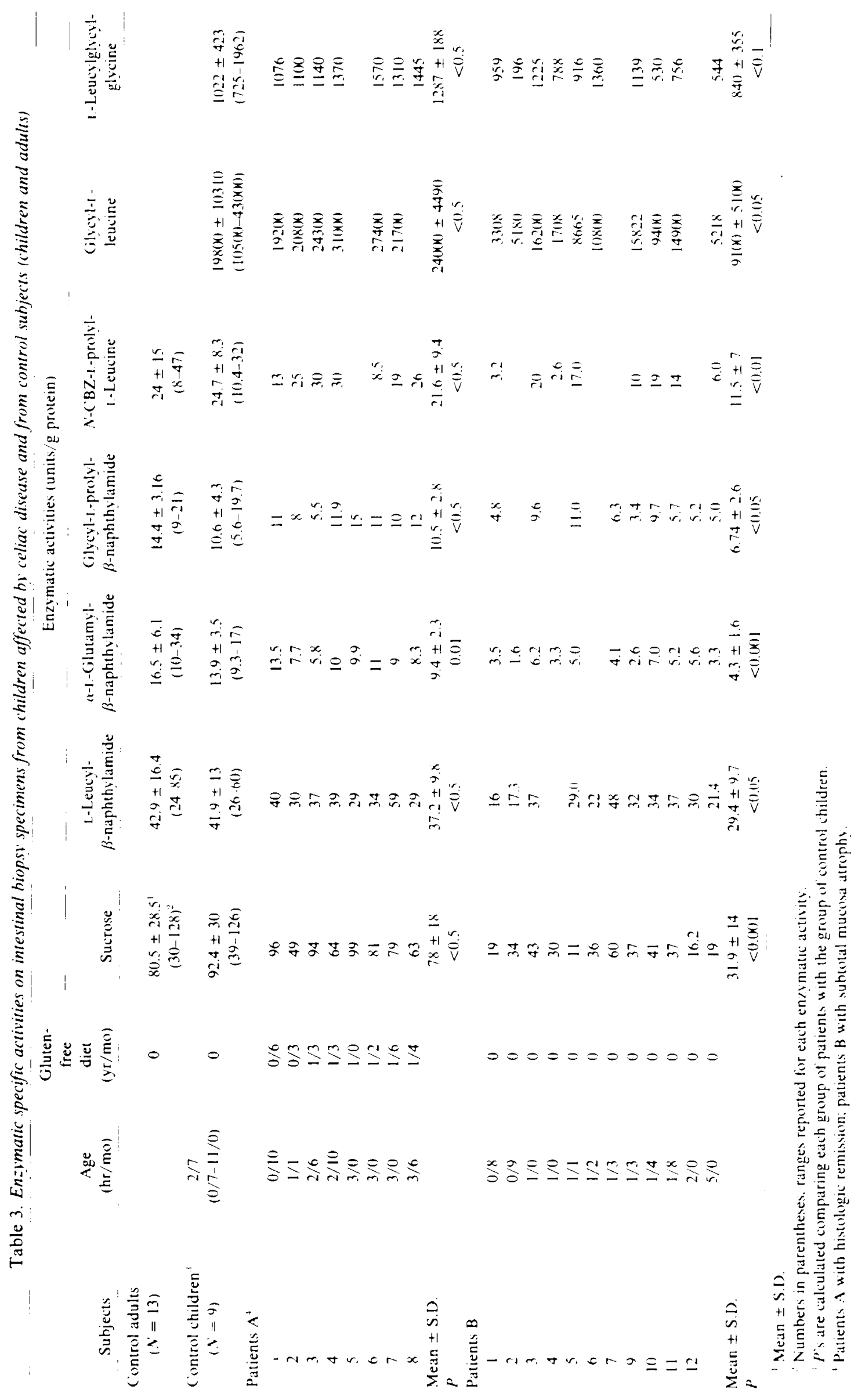


tidase, the oligoaminopeptidase, the aminopeptidase $A$, and the carboxypeptidase (6). We have not found similar enzymes in acrylamide gel electrophoresis of papain-solubilized human enzymes. In this regard, it is important to stress that in human as in rabbit (6) only a small amount of glycyl-L-leucine hydrolase activity of brush border is solubilized by papain. Further research on purified enzymes and with different solubilization techniques is necessary to know if other peptidases are present in human brush border in addition to the 4 major peptidases described in this paper, as it has been suggested by preliminary results of Sterchi and Woodley (64) and of Yeh et al. (69).

The main clinical interest of the results presented here is that it is possible, utilizing the substrates in this study, to selectively measure four different peptidases of the human brush border in total homogenate of mucosal biopsies because the enzymatic activities measured on these substrates are almost totally located in the brush border.

\section{PIPTIDASE ACTIVITIES IN CELIAC CHILDREN}

Some of the brush border peptidases studied, namely aminopeptidase A, carboxypeptidase, and dipeptidylaminopeptidase IV. are able to hydrolyze peptide bonds containing glutamic acid and proline. These enzymes are probably particularly relevant in the digestion of gliadin, which is very rich in these two amino acids; it is, in fact, well known that pancreatic peptidases are generally not able to split peptide bonds formed by glutamic acid and proline (47). Furthermore, glutamyl peptides are poor substrates of cytosol peptidases $(12,15,16,20.51)$.

These peptidase activities are reduced in the atrophic celiac mucosa (Table 3 ); this finding appears to suggest that during the active disease, digestibility of gliadins peptides is reduced. It is worthwhile emphasizing that not all the peptidase activities studied are equally decreased in the atrophic mucosa. This difference may be due to the fact that certain enzymes of the enterocyte are more affected than others by the disease; it is already well known that lactase shows a greater reduction than does sucrase in the atrophic mucosa of celiac patients (58). Another possibility is that some peptidases are also localized in cells other than the epithelial cell. for example in inflammatory cells, which are numerous in the atrophic mucosa.

The fact that the some peptidase activities were. on the contrary. normal or only slightly reduced (see Table 3 for aminopeptidase A) in histologically recovered mucosa of celiac children further demonstrates that celiac disease is not due to a primary defect of the known intestinal peptidases and that the reduced activities of these enzymes during the active disease is secondary to the mucosal atrophy. Many other peptidase activities have been found to be reduced in intestinal mucosa of celiac patients with mucosal atrophy, whereas they return to normal in these patients during histologic remission $(4,10,27,40,45,56,68)$.

Aminopeptidase $A$ was the only significantly reduced peptidase activity, compared to controls in children with celiac disease in complete or almos complete histologic remission after a glutenfree diet. It is well known that lactase activity also remains low in intestinal tissue from children with celiac disease in remission (31. 58): one possible explanation is that some brush border enzymes are more sensitive to the disease than others and that, likewise. recovery is slower. A second possibility is that the gluten-free diet decreases the brush border aminopeptidase A activity.

\section{REFIREN(ES AND NOTHS}

1. Andria. (i., Marit. A.. and Auricchio. S.: Peptidase activities of the brush border of rabhit small intestinal mucosa. Pediatr. Res. (Abstract). $8: 141$ (1974).

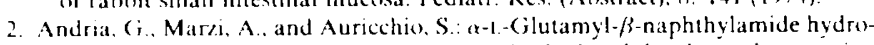
lase of rabbit small intestine. Localization in the brush border and separation from other brush border peptidases. Biochim. Biophys. Acta, 4/4: 42 (1976).

3. Auriciho, S.. Andria, (j.. (ireco, L.. and Mazacca. (i.. Peptidases of brush border of human and rabbit small intestinal mucosa. Pediatr. Res. (Abstract). 10: $879(1076)$.

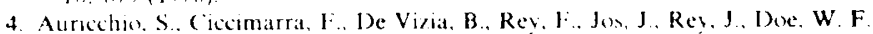
and Booth. $(\therefore$. C Peptidane activities of intestinal muctisa in cereliac disease. Riv. Ital. Ped. 2: 31 (1970).
5. Auricchio, S., Ciccimarra, F., Vegnente, A., Andria, G., and Vetrella. M. Enzymatic activity hydrolyzing $\gamma$-glutamyl- $\beta$-naphthylamide in human intestine during adult and fetal life. Pediatr. Res., 7: 95 (1973).

6. Aurichio. S.. (ireco, L.., De Vizia, B.. and Buonocore, V.: Dipeptidylaminopeptidase and carboxypeptidase activities of the brush border of rabbit small intestine. (jastroenterology. 75: 1073 (1978).

7. Auricchio, S.. (ireco, L., and liorillo, A.: Peptidases of brush border. Acta Paediatr. Belg. (Abstract), 29: 204 (1976).

x. Auricchio, S.. Pierro, M.. Andria, G., and de Ritis, G.: Enzymic activities of the brush horder membrane of rat intestine hydrolyzing $\beta$-naphthylamides of amino acids, leucinamide and dipeptides. Biochim. Biophys. Acta, 274: 420 (1972).

9. Auricchio, S., Pierro, M., and Orsatti, M.: Assay of peptidase activities of intestinal brush border membrane with $\mathrm{t}$-amino acid oxidase. Anal. Biochem.. 34: $15(1971)$

10. Berg. N. O.. Dahlyvist. A.. Lindberg. T.. and Norden, A.: Intestinal dipeptidases and disaccharidases in celiac disease in adults. Gastroenterology, 54: 575 $(1970)$.

11. Booth, G. A., and Kenny, A. J.: Identification of protein subunits in the kidney microvillus membrane. Biochem. Soc. Trans., 4: 348 (1976).

12. Cuinn, (;. O., and Fottrell, P. F.: Puritication and characterization of an aminoacylproline hydrolase from guinea pig intestinal mucosa. Biochim. Biophys Acta, 391: $38 \times(1975)$.

13. Curtis, K. J.. (iaines, H. D.. and Kim. Y. S.: Protein digestion and absorption in rats with pancreatic duct occlusion. (iastroenterology. 74: 1271 (1978).

14. Danielsen. E. M.. Sjoström. H., Noren, O., and Dabelsteen, E.: Immunoelectrophoretic studies on pig intestinal brush border proteins. Biochim. Biophys Acta, 494: 332 (1977).

15. Das, M., and Radhakrishnan. A. N.: Substrate specificity of a highly active dipeptidase puritied from monkey small intestine. Biochem. J.. 128:463 (1972).

16. Das. M., and Radhakrishnan, A. N.: Glycyl-1-leucine hydrolase, a versatile "Master" dipeptidase from monkey small intestine. Biochem. J., 1.35: 6094 (1473).

17. Das, M.. and Radhakrishnan. A. N.: A comparative study of the distribution of soluble and particulate glycyl-L-leucine hydrolase in the small intestine. Clin. Sci. Mol. Med.. 40: 501 (1974).

18. Das, M., and Radhakrishnan. A. N.: Studies on a wide-spectrum intestinal dipeptides uptake system in the monkey and in the human. Biochem. J., 146 133 (1975).

19. Davidson, M.. and Wasserman, R.: The irritable colon of childhood. J. Pediatr. 69: $1027(1960)$

20. Donlon. J.. and Fottrell, P. F.: Purification and characterization of one of the forms of peptide hydrolases from guinea pig small intestinal mucosa. Biochim. Biophys. Acta, 327: 425 (1973).

21. Fujita. M., Parsons, D. S... and Wojnarowska. F.: Oligopeptidases of brush border membranes of rat small intestinal mucosal cells. J. Physiol. (Lond.), 227: 377 (1972).

22. (iray, (;. M.. and Santiago, N. A.. Human jejunal surface amino-oligopeptidase sequential and simultaneous action on a tetrapeptide and its products. (jastroenterology (Abstract), o6: 7(14 (1974).

23. (iray, (;. M.. and Santiago, N. A.: Intestinal surface aminooligopeptidase. I lswlation of two weight isomers and their subunits from rat hrush border. J Biol. ('hem. 252: 4922 (1977).

24. Hartsuck, J. A.. and Lipscomb. W. N.: Carboxypeptidase A. In: P. D. Boyer: The Enzymes. Vol. 3, pp. 156 (Academic Press Inc.. New York. 1971)

25. Heizer. W. I)., Kerley. R. L... and Isselbacher. K. J.: Intestinal peptide hydrolases differences between brush border and cytoplasmatic enzymes. Biochim. Biophys. Acta. 204: 450) (1972).

26. Heizer, W. D.. and Laster. I... Hydrolases in the mucosa of rat small intestine for phenylalanine containing dipeptides. Biochim. Biophys. Acta, 185:409 (1969).

27. Heizer. W. D., and I.aster. L.: Peptide hydrolase activities of the mucosa of human small intestine. J. (lin. Invest., 4.: 210)(1969).

28. Heizer. W. D.. and Shoaf, C. R.: Brush border and cytoplasmic peptide hydrolase activities in human intestinal biopsies. (iastroenterology (Abstract), 04: 742 (1973).

29. Holt, J. H. and Miller, D.: The locialization of phosphomonosesterase and aminopeptidase in brush border isolated from intestinal epithelial cells. Biochim. Biophys. Acta. 58: 239 (1962).

30. Hopsu-Havu, V. K., Kantonen. U. M.. and (jlenner, (;. G.: A peptidase from rat

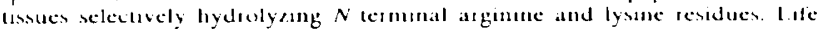
Sci... 3: $1449(1964)$

31. Jos. J.. Frézal. J.. and Rey. J.: Etude histochimique de la muquese duodenojejunale dans la maladie coeliaque. Pediatr. Res., 1: 27 (1967).

32. Joseffson. L... and Sjostrom. H.: Intestinal dipeptidases. IV. Studies on the release and subcellular distribution of intestinal dipeptidase of the mucosa cells of the pig. Acta Physiol. Scand.. 67: 27 (1966).

33. Kania, R. J., Santiago, N. A. and (iray. G. M.: Intestinal cell surface peptidase potential role in protein digestion. (Gastroenterology (Abstract). 02: 768 (1972)

34. Kenny. A J., Booth. A. (;.. Cieorge, S. (;.. Ingram, J.. Kershaw, D.. Wood. E. and Young. A. R.: Dipeptidyl peptidase IV. a kidney brush-border serine peptidase. Biochem. J., 155: 169 (1976).

35. Kim. Y. S., Birtwhistle, W., and Kim, Y. W.: Peptide hydrolases in the brush border and soluble fractions of small intestinal mucosa of rat and man. J. (lin. invest.. 51: $1419(1972)$

36. Kim, Y. S.. and Brophy. E. J.: Rat intestinal brush border membrane peptidases 1. Solubilization, purification and physicochemical properties of two different forms of the enzyme. J. Biol. (hem., 25/: 3199 (1976).

37. Kim, Y. S.. Brophy, E. J., and Nicholson, J. A.: Rat intestinal brush border 
membrane peptidases. II. Enzymatic properties, immunochemistry and interactions with lectins of two different forms of the enzyme. J. Biol. Chem., 25/. $3206(1976)$.

38. Kim, Y. S. Kim. Y. W., and Sleisenger. M. H.: Studies on the properties of peptide hydrolases in the brush border and soluble fractions of small intestinal mucosa of rat and man. Biochim. Biophys. Acta, 370: 283 (1974)

39. Kim, Y. S. Mc Carthy, D. M. Lane, W. and Fong, W. Alterations in the levels of peptide hydrolases and other enzymes in brush border and soluble fractions of rat small intestinal mucosa during starvation and refeeding. Bicchim Biophys. Acta. 321: 262 (1973).

40. Lindberg. T. Norden, A.. and Josefsson. L.: Intestinal dipeptidases. Dipeptidase activities in small intestinal biopsy specimens from a clinical material. Scand. J. Gastroenterol., 3: 177 (1968).

4I. Lowry, O. H., Rosebrough. N. J.. Farr, A. L.. and Randall, R. J.: Protein measurements with the folin phenol reagent. J. Biol. Chem., 19.3: 265 (1951).

42. Maroux. S., Louvard, D., and Baratti. J.: The aminopeptidase from hog intestinal brush border. Biochim. Biophys. Acta, 321: 282 (1973)

43. Matthews, D. M., Addison. J. M.. and Burston. D.: Evidence for active transpor of the dipeptide carnosine ( $\beta$-alanyl-1.-histidine) by hamster jejunum in vitro. ( lin. Sci. Mol. Med., 46: 693 (1974)

44. Moore. G. J.. and Benoiton. N. L.: Effect of modifiers on the hydrolysis of basic and neutral peptides by carboxypeptidase B. Can. J. Biochem. 53:747 (1975)

45. Morin (C, L. Roy. C. C. Lasalle, R and Bonin. A.: Small bowel mucosal dysfunction in patients with cystic fibrosis. J. Pediatr. 8.8: 213 (1976).

46. Nicholson. J. A.. McCarthy. D. M.. and Kim, Y. S.: The response of rat intestinal brush border and cytosol peptide hydrolase activities to variation in dietary protein content. J. Clin. Invest., 54: 890 (1974).

47. Nordwig. A., and Dehm, P.: Breakdown of protein: cleavage of peptides of the X-Pro-Y type by kidney peptidases. Biochim. Biophys. Acta, 160): 293 (1968).

48. Noren. O.. Sjostrom. H., and Josefsson. L.: Studies on a soluble dipeptidase from pig intestinal mucosa. I. Purification and specificity. Biochim. Biophys. Acta. 327: 446 (1973)

49. Peters. T. J.: The subcellular localization of di- and tripeptide hydrolase activity in guinea pig small intestine. Biochem. J., 120: 195 (1970)

50. Peters, T. J.: The hydrolysis of glycine oligopeptides by guinea pig intestinal mucosa and by isolated hrush border. (lin. Sci. Mol. Med. 45: 803 (1973).

51. Piggott. C. O.. and Fottrell, P. F.: Purification and characterization from guinea pig intestinal mucosa of two peptide hydrolases which preferentially hydrolyze dipeptides. Biochim. Biophys. Acta, 391: 403 (1975)

52. Rhulen. J.. and Rhodes. J. B.: Hydrolysis of related tri- and dipeptides hy hamster microvillus membranes. Gastroenterology (Abstract), 66: 863 (1974).

53. Robinson, G. B.: The distribution of peptidases in subcellular fractions from the mucosa of the small intestine of the rat. Biochem. J., 88 : 162 (1963).

54. Rolls. B. A.: Dipeptidase activity in the small intestinal mucosa during pregnancy and lactation in the rat. Br. J. Nutr. .3.: I (\$975).

55. Rubino, A., Field. M.. and Schwachman. H.: Intestinal transport of amino acid residues of dipeptides. I. Influx of the glycine of glycyl-1.-proline across mucosal border. J. Biol. Chem.. 246: 3542 (1971)

56. Rubino, A., Vetrella, M.. Pierre, M.. Jos. J., Rey, J., and Auricchwo, S.: Intestunal glutaminylproline dipeptidase activity in children with treated coeliac disease Rev. Eur. Etud. Clin. Biol. 17: 993 (1973).

57. Schmitz, J.. Preiser. H.. Maestracci, D.. Ghosh, B. K., ('erda. J. J.. and (rane. R. $K$.: Purification of the human intestinal brush border membrane. Biochim. Biophys. Acta, 323: 98 (1973).

5x. Shmerling, D. H.. Auricchio, S. Rubino, A. Hadorn. B. and Prader. A. De sekundare Mangel an intestinaler Disaccharidaseaktivitat hei der Coliakie. Quantitative Bestimmung der Enzymaktivitat und klinische Beurteilung. Helv. Paediatr. Acta. 19: 507 (1964).

59. Shoaf, C. R.. Berko, R. M., and Heizer, W. D.: Isolation and characterization of four peptide hydrolases from the brush border of rat intestinal mucosa. Bickim. Biophys. Acta. 445: 694 (1976).

60. Shoaf. C. R.. Isselhacher, M. J., and Heizer. W. D.: Rapid colorimetric assay for intestinal peptide hydrolase. Anal. Biochem., 61: 72 (1974).

61. Sjostrom. H. Noren, O. Jeppesen L. Staun, M Svensson, B and Christiansen. L.: Purification of different amphiphilic forms of a microvillus aminopeptidase from pig small intestine using immunoadsorbent chromatography. Eur. J. Biochem.. s4: 503 (1978).

62. Sjostrom. H.. Norén, O., and Josefsson. L.: Purification and specificity of pig intestinal prolidase. Biochim. Biophys. Acta, 327: 457 (1973)

63. Skovbjerg. H.. Noren. O.. and Sjostrom. H.: Immunoelectrophoretic studies on human small intestinal brush border proteins. Scand. J. Clin. Lah. Invest.. 3. $723(1978)$.

64. Sterchi, E E and Woodley, J F. Peptidases of the human intestinal brush border membrane. In: B. McNicholl. C. F. Mc Carthy. P. F. Fottrell: Perspectives in coeliac disease. pp. 437-449 (MTP Press Limited. 1978)

65. Svensson. B., Danielsen, M., Staun, M., Jeppesen. L... Noren. O.. and Sjostrom. H.: An amphiphilic form of dipeptidvl peptidase IV from pig small intestinal hrush border membrane. Eur. J. Biochem.. $40: 489(1978)$

66. Takesue. $Y_{\text {.: }}$ Purification and properties of leucine- $\beta$-naphthylamidase from rabbit small intestinal mucosal cells. J. Biochem., $7 ?$ : 103 (1475).

67. Wojnarowska, F and Gray, G. M : Intestinal surface peptide hydrolases identification and characterization of three enzymes from rat brush border. Biochim. Biophys. Acta. 40.3: 147 (1975).

68. Woodley, J. F.: Pirrolidonecarboxylyl peptidase activity in normal intestinal biopsies and those from coeliac patients. (lin. (him. Acta. 42: 211 (1972)

69. Yeh, R.. Huang. T. J.. and Heizer. W. D.: Peptide hydrolases of the brush border of human intestinal mucosa. (iastroenterology, $4: 1114$ (1978).

70. This work was presented in part at the 9th Annual Meeting of the Furopean Society for Paediatric (jastroenterology. Weimar. Cierman Democratic Republic. May 20-21, 1976, and at the Meeting of the Furopean Society for Paediatric Research. Rotterdam. Holland. June 20 24, 1976. Preliminary reports of this work have been published in abstract form $(3,7)$.

71. The authors wish to thank Dr. A. Trapani, (hief of the loth (ieneral Surgery Unit. Ospedale (ardarelli, Naples, for providing jejunal mucosa samples.

72. Requests for reprints should be addressed to: S. Auricchio. M.D.. (Clinica Pediatrica-II Facolta di Medicina e Chirurgia. Universita di Napoli. Via S Pansini, 5, 80131 Napoli. Italy.

73. Received for publication April 2. 1979

74. Accepted tor publication August 13. 1979 